\title{
Malignant Prostate Neoplasm
}

National Cancer Institute

\section{Source}

National Cancer Institute. Malignant Prostate Neoplasm. NCI Thesaurus. Code C7378.

A primary or metastatic malignant tumor involving the prostate gland. The vast majority are carcinomas. 